\title{
SIGNIFICANCE OF PROTECTED AREAS FOR THE PALLAS'S CAT (OTOCOLOBUS MANUL: FELIDAE) CONSERVATION IN RUSSIA
}

\author{
Anna N. Barashkova ${ }^{1}$, Vadim E. Kirilyuk ${ }^{2}$, Ilya E. Smelansky ${ }^{1}$ \\ ${ }^{1}$ Sibecocenter, Russia \\ ${ }^{2}$ Daursky State Nature Biosphere Reserve, Russia \\ e-mail:yazula@yandex.ru
}

Received: 12.04.2017

\begin{abstract}
The Pallas's cat, or Manul, Otocolobus manul, belongs to the small felines. In Russia this species is located at the northern periphery of its range. Potential habitats of this species within its Russian range's part have been highlighted on the base of remote sensing data, topographic maps and digital cartographic models. Maps of the Pallas's cat's records in Russia have been compiled using literature data, authors' own data and information provided by contributors of the online database «Small Wild Cats of Eurasia». We have shown the representation of potential habitats of the Pallas's cat and its actual registrations within Protected Areas of Russia. The total area of potential habitats for this species in Russia is assessed as $145,150 \mathrm{~km}^{2}$. The presence of Manul is confirmed for five regions of Russia: Republic of Altai, Republic of Tyva, Republic of Buryatia, Krasnoyarsk Krai, Trans-Baikal Krai. The registration of the species' records mainly corresponds to the location of its potential habitats. The main categories of both federal and regional Russian Protected Areas cover 10.8\% (13.5\% taken with the buffer zones) of the total area of potential habitats for the Pallas's cat. The significance of each Protected Area for Manul conservation has been considered in detail. We have discussed whether the representativeness of the existing Protected Areas is sufficient for conservation of this species. We have identified the main territorial gaps that reduce the Pallas's cat protection in some parts of the Russian range.
\end{abstract}

Key words: distribution, online database, Otocolobus manul, Pallas's cat, potential habitats, Protected Areas, territorial protection, territorial protection gaps

\section{Introduction}

The Pallas's cat or Manul, Otocolobus manul Pallas, 1776, belongs to the small cats (Fig. 1). In Russia this species is located at the northern periphery of its global range and associated mainly with mountain-steppe areas along the border with Mongolia. There the species inhabits the steppes of the Central Asian type. These occupy more or less extensive areas in South Siberia from the Southeast Altai to Dauria (Gadghiev et al., 2000).

General aridity and coincidence of most part of precipitation to the summer period are typical for the climatic conditions of this region. As a consequence, while the severity and relatively long duration are typical for the winter period, the snow cover is usually shallow or it may be absent in some places (especially in Dauria) during most of the winter period. Shallow snow cover is a crucially important circumstance for Pallas's cats (Kirilyuk \& Puzansky, 2000).

The Manul is considered as a naturally rare species. In the XX century the species was impacted by the significant reduction of the area of suitable habitats due to agricultural development. In the same period the global population number had decreased, in particular as a result of massive pesticides use. The Manul is listed on the IUCN
Red List as Near Threatened (Ross et al., 2016). Also it is listed in the Red Data Book of the Russian Federation (2001) and the Red Data Books of all five Russian provinces where it is reliably known: Republic of Altai (2007), Republic of Tyva (2002), Republic of Buryatia (2013), Krasnoyarsk Krai (2012), and Trans-Baikal Krai (2012).

One of the main ways to implement the conservation status of the Pallas's cat is its providing by territorial protection (along with the prohibition of hunting and its derivatives trafficking). It is necessary to assess the level of the species' protection within the Protected Areas to judge the effectiveness of the species' conservation and to plan further conservation efforts.

Until 1978, the Pallas's cat was an object of hunting. Its abundance and distribution could be judged by the massive data on harvested skins. Since its inclusion in the Red Data Book of the USSR (1978, 1984), the Pallas's cat's hunting was banned completely. Obviously, this effort has reduced the anthropogenic pressure on the species. But this also has interrupted the receipt of data which were the base for the estimation of the abundance and distribution of this rare species. At the same time, very few studies on the Pallas's cat have been carried out in Russia until the last 
decade. Most of them were conducted in limited areas. Monitoring studies were conducted in the Daursky Reserve. Nutrition and behaviour of this rare species were studied (Kirilyuk, 1999; Kirilyuk \& Puzansky, 2000). In the Republic of Tyva, counts of the Manul were conducted several times in the framework of the creation of the rare animal species cadastre and to clarify the catch quotas of animals for zoos (Barashkova, 2005; Report on scientific work, 2006). The Laboratory of Ecology and Systematics of Animals of the Institute of General and Experimental Biology of the Siberian Branch of RAS has also conducted several winter surveys in Buryatia (Borisova, personal communication). In the late 1980s - early 1990s, the Central Research Laboratory of the Main Hunting Agency organised a questionnaire survey. According to its results, expert estimates of the abundance of the Pallas's cat in the regions were conducted. These data were included in the first edition of the Red Data Book of the Russian Federation (2001). Barashkova (2005) carried out the overview of the Manul population status and the state of knowledge on this species in Russia. In subsequent years, the distribution and abundance of the Pallas's cat in Russia are systematically studied in the framework of a long-term project of the Sibecocenter in cooperation with the Daursky Reserve, the Uvs Nuur
Basin (Ubsunurskaya Kotlovina) Reserve and the Sailugem National Park. Some reserves and national parks have established the monitoring studies of abundance and occurrence frequency of the Pallas's cat using the method of winter snow track census and the systematic installation of camera traps. In recent years the A.N. Severtsov Institute of Ecology and Evolution of RAS, in co-operation with the Daursky Reserve, have begun studies on the diseases of the Pallas's cat (Naidenko et al., 2014; Pavlova et al., 2015).

\section{Material and Methods}

The map of potential habitats of the Pallas's cat was prepared using the GIS software (ArcView 3.3, ArcGIS 9.3, ESRI, CA, USA) on the base of the topographic map (scale 1:200,000) with clarification of the terrain pattern using satellite imagery (Landsat), landscape map, digital terrain model taking into account the survey results, literature data and other information about the species' habitats. Additionally, we used our own data obtained during field studies of the Manul (winter track counts, collection of interview data) in the Republic of Altai, Republic of Tyva, Republic of Buryatia, Trans-Baikal Krai in 1994-2017, and unpublished data from the online database «Small Wild Cats of Eurasia» (Barashkova et al., 2017).

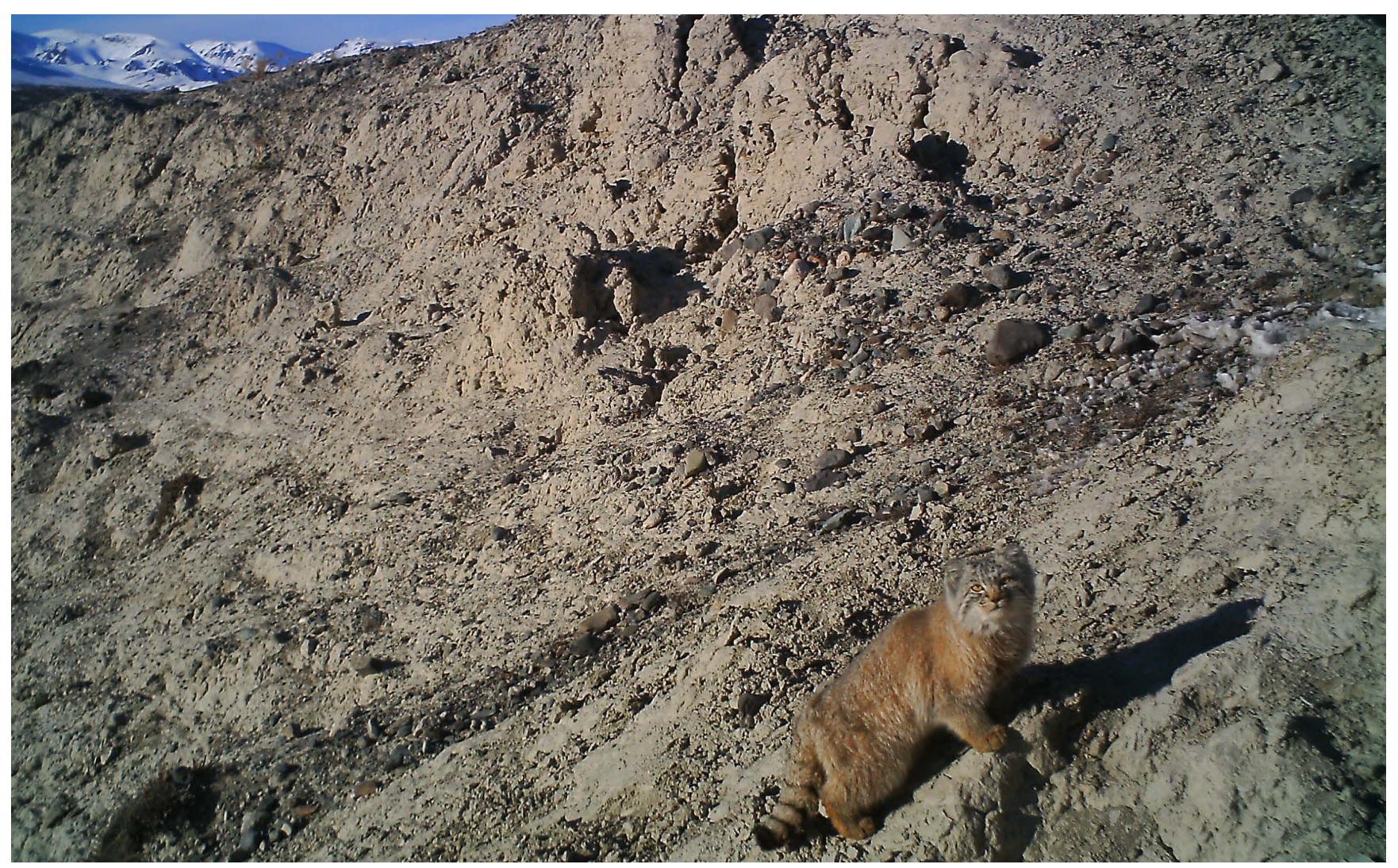

Fig. 1. Pallas's cat captured by a camera trap in the valley of the river Chagan-Uzun (Republic of Altai) in 2014. 
As potential habitats of the Pallas's cat, we have taken various mountain-steppe and steppe ecosystems in Russian part of the species' range. Among them there are high-mountain cryophytic steppes and steppe shrubs thickets, intrazonal biotopes located in steppe zone and in steppe belts of highmountain systems: rock outcrops and screes, floodplain tree-shrub complexes, island pine and larch forests. Based on this map, we have determined the area of potential habitats for the Pallas's cat for each region of Russia and their total area in Russia.

We have combined the obtained map of potential habitats with the digital map (GIS layer) of Protected Areas in Russia (Kalikhman et al., 2012; Map of remained steppe ecosystems (steppe massifs) of Russia, 2017; Map of Protected Areas of Russian Federation, 2017). We have accounted all Protected Areas types of federal and regional significance, except for nature monuments and botanical gardens, because their total area is relatively small. Table 1 presents the main characteristics of Protected Areas in the regions where the Manul is known. These data are presented according to regional state reports on the environment state for 2015 (The report, 2016a,b; The state report, 2016a,b,c).

Through superimposing GIS-layers, we obtained the intersection of Protected Areas contours with the contours of potential habitats of the Pallas's cat. Thus, we have determined the potential habitat's areas located within the boundaries of Protected Areas. On the basis of these parameters, we have counted: a) percentage of the area of potentially suitable habitats for the Pallas's cat within each concrete Protected Area; b) percentage of potential habitats' area located within Protected Areas for each region.
Undoubtedly, the Pallas's cat uses the habitats within the range with different intensity. So, previously, key areas and habitats of the Pallas's cat supporting existence of its population were identified for some territories within structure of species' habitats (Barashkova et al., 2010; Kirilyuk \& Barashkova, 2011; Barashkova, 2012). In this article, we consider the potential habitats of the Pallas's cat without taking into account their ecological heterogeneity and actual inhabitation by animals.

Calculations were conducted using the software MS Excel 2003 and PAST 3.14 (Hammer et al., 2001).

\section{Results and Discussion}

The Pallas's cat is reliably known in five regions of Russia: Republic of Altai, Republic of Tyva, Republic of Buryatia, Krasnoyarsk Krai, and Trans-Baikal Krai. The Protected Areas networks are more or less well-developed in these regions. It includes Protected Areas of different types and levels. Taken together, 120 Protected Areas were known in these regions at the beginning of 2016 (latest available official data). Among them are 29 Protected Areas of federal significance (state nature reserves, national parks, and federal wildlife sanctuaries) and 91 Protected Areas of regional significance (nature parks and regional wildlife sanctuaries) (Table 1).

According to our estimation, the total area of potential habitats for the Pallas's cat in the five abovementioned regions of Russia is $145,150 \mathrm{~km}^{2}$ (Fig. 2, Table 2). The largest areas of potential habitats for the Pallas's cat are presented in Trans-Baikal Krai and Tyva (Table 2). The smallest ones are in Krasnoyarsk where these are limited by small tract in Sayan highlands, near the border with Tyva.

Table 1. Main characteristics of the Protected Areas in the regions of Russia where the Pallas's cat is known

\begin{tabular}{|l|c|c|c|c|}
\hline \multicolumn{1}{|c|}{ Regions of Russia } & $\begin{array}{c}\text { Region area, } \\
\mathrm{km}^{2}\end{array}$ & $\begin{array}{c}\text { Number of Protected Areas (federal sig- } \\
\text { nificance / regional significance) }\end{array}$ & $\begin{array}{c}\text { Protected Areas in } \\
\text { total, } \mathrm{km}^{2} * *\end{array}$ & $\begin{array}{c}\text { Percentage of Protected Areas } \\
\text { of total area of a region, } \%\end{array}$ \\
\hline Republic of Altai & 92903 & $9(3 / 6)$ & 23116.8 & $\begin{array}{c}19246.65 \\
(26166.03)\end{array}$ \\
\hline Republic of Tyva & 168604 & $17(2 / 15)$ & $\begin{array}{c}144240.57 \\
(172938.58)\end{array}$ & $\begin{array}{c}11.41 \\
(15.52)\end{array}$ \\
\hline Krasnoyarsk Krai*** & 723700 & $42(5 / 37)$ & 31099.62 & $\begin{array}{c}19.93 \\
(23.90)\end{array}$ \\
\hline Republic of Buryatia & 351334 & $20(8 / 12)$ & $\begin{array}{c}25527.37 \\
(30173.34)\end{array}$ & $\begin{array}{c}5.85 \\
(6.99)\end{array}$ \\
\hline Trans-Baikal Krai & 431892 & $24(6 / 18)$ & $\begin{array}{c}269434.06 \\
(305051.45)\end{array}$ & $\begin{array}{c}6.44 \\
(7.29)\end{array}$ \\
\hline TOTAL: & 4186376 & $120(29 / 91)$ & & \multicolumn{2}{c|}{} \\
\hline
\end{tabular}

* Except nature monuments and botanical gardens.

** In brackets the Protected Areas are taken with their buffer zones.

*** All the data on the region are without Taymyr Dolgano-Nenets Autonomous District and Evenkia Autonomous District. 


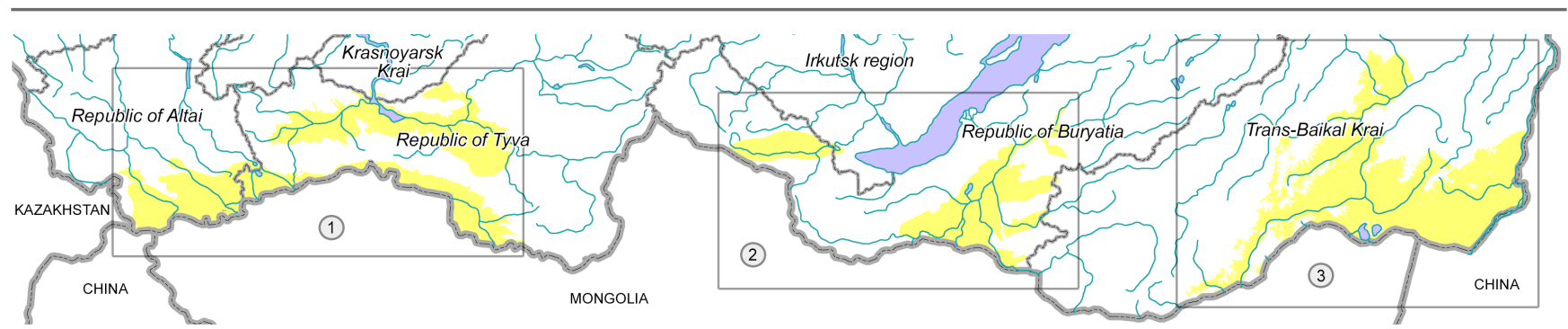

Fig. 2. Potential habitats for the Pallas's cat within its species range in Russia: (1) Altai-Sayan part, (2) Baikal part, (3) Trans-Baikal part.

Table 2. Area of potential habitats for the Pallas's cat and representativeness in the Protected Areas of Russia

\begin{tabular}{|l|c|c|c|c|}
\hline \multicolumn{1}{|c|}{ Region } & $\begin{array}{c}\text { Area of potential } \\
\text { habitats for the } \\
\text { Pallas's cat, km }{ }^{2}\end{array}$ & $\begin{array}{c}\text { Percentage of potential } \\
\text { habitats for the Pallas's } \\
\text { cat located within federal } \\
\text { Protected Areas, \%* }\end{array}$ & $\begin{array}{c}\text { Percentage of potential } \\
\text { habitats for the Pallas's } \\
\text { cat located within region- } \\
\text { al Protected Areas, \% }\end{array}$ & $\begin{array}{c}\text { Percentage of potential } \\
\text { habitats for the Pallas's } \\
\text { cat located within all } \\
\text { Protected Areas, \% }\end{array}$ \\
\hline Republic of Altai & 16,000 & 9.2 & 16.7 & 25.9 \\
\hline Republic of Tyva & 37,800 & $1.4(6.7)$ & 2.9 & $4.3(9.6)$ \\
\hline Krasnoyarsk Krai & 350 & 57.1 & 3.1 & 57.1 \\
\hline Republic of Buryatia & 28,900 & 17.2 & 2.0 & 20.3 \\
\hline Trans-Baikal Krai & 62,100 & $4.2(7.9)$ & 4.1 & $6.2(9.9)$ \\
\hline TOTAL: & 145,150 & $6.7(9.5)$ & $10.8(13.5)$ \\
\hline
\end{tabular}

* data in brackets are the percentage of potential habitats for the Pallas's cat as the Protected Areas are taken with their buffer zones (if any exist).

Due to the wide use of camera traps, it is now known that the Pallas's cat uses a wider habitat range than previously assumed. Hence, the actual Manul distribution in Russia is somewhat wider than it is shown on our map of potential habitats. This is evidenced by the compactly placed points of the Pallas's cat registration outside the highlighted area. However, the vast majority of this species' meetings are indeed confined to the identified potential habitats (Fig. 3, 4, 5).

As Table 2 shows the percentage of potential habitats for the Pallas's cat located within federal Protected Areas is significantly different depending on the province. The figure ranges from slightly more than $4 \%$ (about 10\% taking into account areas of buffer zones too) to more than $57 \%$. Naturally, the coverage of manul's habitats by Protected Areas will be higher if the absolute area of Manul's habitats in the region will be less. There is a strong negative correlation between these measures $(\mathrm{r}=$ $-0.87, \mathrm{p}<0.9$ ). A comparison between regions with the highest area of potential habitats located within the Protected Areas (Altai, Krasnoyarsk, and Buryatia) shows that the regional Protected Areas (especially the Ukok Quiet Zone Nature Park - see Table 3) make the main contribution to the overall protection of potential habitats of the Pallas's cat in the Republic of Altai while federal ones in the other two regions. For example, $100 \%$ of all its habitats located within Protected Areas are situated within the Sayano-Shushensky Reserve in the Krasnoyarsk Krai (Table 3). The situation for each Protected Area or its specific site is presented in Table 3.

Below we characterise the representation and protection level of potential habitats of the Pallas's cat, the species' actual distribution, and the state of its study in each of the five regions where the species is known.

\section{Republic of Altai}

In this region the total area of potential habitats for the Pallas's cat has been estimated at 16,000 $\mathrm{km}^{2}$ (Table 2, Fig. 3). The Pallas's cat's distribution is mostly studied in the foothills of mountain ranges bordering the Chuya hollow. Special studies (winter track transects and interview surveys) were conducted on the Sailugem and Kuraisky ridges in 2006 and 2009 (Naidenko et al., 2007; Barashkova et al., 2010; Barashkova \& Smelansky, 2011). The Sailugem ridge was recognised as a population hotspot for the Pallas's cat, where the maximum population density of this species has been registered (up to 1.96 individuals per $10 \mathrm{~km}^{2}$ ). The total abundance of the Manul in Altai has been assessed at 650-680 individuals (Barashkova et al., 2010). Since 2012, some new data on the Pallas's cat have been obtained through the camera traps usage, specifically in the valleys of Chagan-Uzun, Ulandryk, 
and Bolshie Shibety, the foothills of Chikhachev's ridge, and the Talduair mountain massif (Barashkova \& Smelansky, 2016). The Altai Anti-Plague Station working in these areas also regularly recorded the Pallas's cat (Denisov et al., 2015). By the use of camera traps to study the Snow Leopard in the highlands, it was found that the Pallas's cat is wider distributed in the region than it has been assumed earlier. So, this cat was repeatedly recorded by camera traps on the Chikhachev's ridge at altitudes of about $3000 \mathrm{~m}$ above sea level and in the Argut river basin (Spitsyn, 2017), where this species had not been known previously. The Ukok Plateau and the southern parts of the Shapshalsky and Chulyshmansky ridges remain to be the least studied areas in the region. It is not completely clear how the Pallas's cat is distributed in the Argut river basin and in the Kurai hollow. Apparently, the knowledge about the distribution area of the Pallas's cat in the Altai will change significantly if new information becomes available.

Potential habitats of the Pallas's cat in the region are represented by two federal Protected Areas, Sailugem National Park and Altai State Biosphere
Reserve (Table 3). The species' presence has been recently confirmed in the Argut site within the Sailugem NP (Spitsyn, 2017). The Pallas's cat has been recorded every year in the Sailugem and Ulandryk sites located on the Sailugem ridge. However, the species key habitats have not been included in the national park boundaries. The Pallas's cat's inhabitation in the Altai Reserve has not been confirmed yet. The species can be found there in the vicinity of the Dzhulukol lake, at the junction of Chikhachev's, Shapshalsky, and Chulyshmansky ridges.

The Manul's habitats on Argut and in the south of the Altai Reserve are not accurately delineated yet. Therefore, based on our expert assessment of their areas, we can only assume that about $9 \%$ (probably less) of the total area of the Pallas's cat's habitats is located within the federal Protected Areas in the Republic of Altai (Table 2). The habitats suitable for the Pallas's cat occupy about $69 \%$ of the Sailugem $\mathrm{NP}$ area. However, these are not the optimal stations of this species. In the autumn of 2016, studies of the Pallas's cat using camera traps were started in Sailugem NP and adjoining area. This will allow us to clarify the cat's status in this Protected Area.

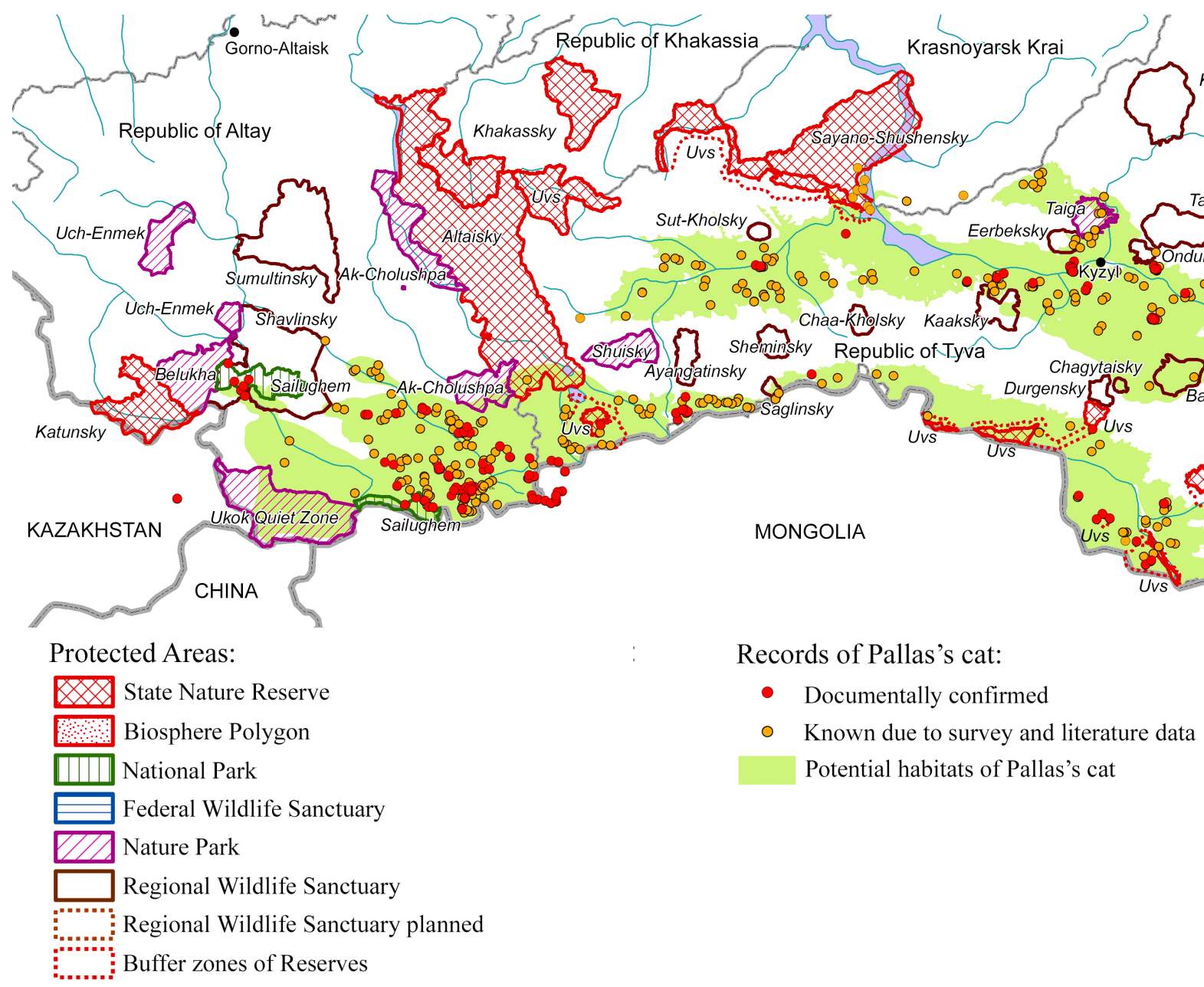

Fig. 3. Distribution of the Pallas's cat in the Altai-Sayan part of its Russian range.

Note: «Uvs» - the sites of the Uvs Nuur Basin Biosphere Reserve. 
Table 3. Potential habitats for the Pallas's cat and its actual representativeness within Protected Areas network of Russia

\begin{tabular}{|c|c|c|c|c|c|}
\hline Protected Area & Region & $\begin{array}{c}\text { Total area of } \\
\text { Protected Area* }\end{array}$ & $\begin{array}{c}\text { Percentage from total } \\
\text { area of all potential } \\
\text { habitats for the Pallas's } \\
\text { cat in Russia, } \% *\end{array}$ & $\begin{array}{c}\text { Percentage } \\
\text { from area of the } \\
\text { specific Protected } \\
\text { Area/site, } \% *\end{array}$ & $\begin{array}{c}\text { Has the Pallas's } \\
\text { cat existence been } \\
\text { confirmed in the last } \\
10-15 \text { years? }\end{array}$ \\
\hline \multicolumn{6}{|c|}{ FEDERAL PROTECTED AREAS } \\
\hline Altaisky BR & Altai & 8712.1 & 0.45 & 7.5 & No \\
\hline Sailugem NP: Argut site & Altai & 807.3 & 0.37 & 66.5 & Yes \\
\hline $\begin{array}{l}\text { Sailugem NP: Sailugem and } \\
\text { Ulandryk sites }\end{array}$ & Altai & 376.5 & 0.19 & 74.4 & Yes \\
\hline $\begin{array}{l}\text { Ubsunurskaya Kotlovina } \\
\text { BR: Mongun-Taiga site }\end{array}$ & Tyva & $\begin{array}{c}158.9 \\
(1015.1)\end{array}$ & $\begin{array}{l}0.11 \\
(0.7)\end{array}$ & $100(99.4)$ & Yes \\
\hline $\begin{array}{l}\text { Ubsunurskaya Kotlovina } \\
\text { BR: Uvs Nuur site }\end{array}$ & Tyva & $\begin{array}{c}44.9 \\
(130.4)\end{array}$ & $\begin{array}{l}0.02 \\
0.08\end{array}$ & $66.8(84.6)$ & Yes \\
\hline $\begin{array}{l}\text { Ubsunurskaya Kotlovina } \\
\text { BR: Oruku-Shynaa site }\end{array}$ & Tyva & $\begin{array}{c}287.5 \\
(638.4) \\
\end{array}$ & $\begin{array}{l}0.16 \\
(0.4)\end{array}$ & $82.8(91.4)$ & Yes \\
\hline $\begin{array}{l}\text { Ubsunurskaya Kotlovina } \\
\text { BR: Aryskannyg site }\end{array}$ & Tyva & $\begin{array}{c}150.0 \\
(264.6)\end{array}$ & $\begin{array}{c}0.01 \\
(0.09)\end{array}$ & $8.0(47.8)$ & Yes \\
\hline $\begin{array}{l}\text { Ubsunurskaya Kotlovina } \\
\text { BR: Yamaalyg site }\end{array}$ & Tyva & $\begin{array}{c}8.0 \\
(54.5) \\
\end{array}$ & $\begin{array}{c}0.01 \\
(0.04)\end{array}$ & $100(100)$ & Yes \\
\hline $\begin{array}{l}\text { Ubsunurskaya Kotlovina } \\
\text { BR: Tsugeer Els site }\end{array}$ & Tyva & $49.0(457.86)$ & $\begin{array}{l}0.03 \\
(0.3)\end{array}$ & $91.8(85.6)$ & Yes \\
\hline $\begin{array}{l}\text { Ubsunurskaya Kotlovina } \\
\text { BR: Khan-Deer site }\end{array}$ & Tyva & $1129.2(2302.5)$ & $\begin{array}{c}0.03 \\
(0.15) \\
\end{array}$ & $4.4(9.6)$ & Yes \\
\hline Sayano-Shushensky BR & Krasnoyarsk & 3903.7 & 0.14 & 5.1 & Yes \\
\hline Tunkinsky NP & Buryatia & 11836.6 & 3.25 & 39.8 & Yes \\
\hline Altacheisky FWS & Buryatia & 783.7 & 0.17 & 31.3 & Yes \\
\hline $\begin{array}{l}\text { Daursky BR: Toreisky, Imal- } \\
\text { kinsky, Chikhalan, Ereldzhi, } \\
\text { and Kuku-Khodan sites }\end{array}$ & Trans-Baikal & $\begin{array}{c}426.7 \\
(1564.2)\end{array}$ & $\begin{array}{c}0.06 \\
(0.62)\end{array}$ & $21.3(57.9)$ & Yes \\
\hline $\begin{array}{l}\text { Daursky BR: three sites at } \\
\text { Adon-Chelon area }\end{array}$ & Trans-Baikal & $\begin{array}{c}10.4 \\
(112.1)\end{array}$ & $\begin{array}{c}0.01 \\
(0.08)\end{array}$ & $100(100)$ & Yes \\
\hline Daursky BR: Lesostepnoy site & Trans-Baikal & $\begin{array}{c}3.0 \\
(42.5)\end{array}$ & $\begin{array}{l}0.002 \\
(0.03)\end{array}$ & $100(99.5)$ & Yes \\
\hline Sokhondinsky BR: buffer zone & Trans-Baikal & $(3180.5)$ & $(0.68)$ & $(31.0)$ & Yes \\
\hline Alkhanai NP & Trans-Baikal & 1382.3 & 0.16 & 16.3 & No \\
\hline Dzerens' valley FWS & Trans-Baikal & 2138.4 & 1.45 & 98.2 & Yes \\
\hline Tsasucheisky Bor FWS & Trans-Baikal & 578.7 & 0.12 & 31.1 & Yes \\
\hline $\begin{array}{l}\text { Total for federal Protected } \\
\text { Areas: }\end{array}$ & & $\begin{array}{c}32786.8 \\
(40331.0)\end{array}$ & $\begin{array}{c}6.74 \\
(9.45) \\
\end{array}$ & $29.8(34.0)$ & \\
\hline \multicolumn{6}{|c|}{ REGIONAL PROTECTED AREAS } \\
\hline $\begin{array}{l}\text { Ak-Cholushpa: NaP Kalba- } \\
\text { kaya site }\end{array}$ & Altai & 789.5 & 0.18 & 33.9 & Yes \\
\hline Belukha NaP & Altai & 1312.7 & 0.08 & 8.6 & No \\
\hline Ukok Quiet Zone NaP & Altai & 2542.0 & 1.26 & 71.8 & No \\
\hline Shavlinsky RWS & Altai & 2466.0 & 0.32 & 19.0 & Yes \\
\hline Taiga NaP & Tyva & 425.5 & 0.13 & 45.8 & Yes \\
\hline Balgazynsky RWS & Tyva & 542.8 & 0.37 & 100 & No \\
\hline Kaksky RWS & Tyva & 487.7 & 0.09 & 27.7 & Yes \\
\hline Ondumsky RWS & Tyva & 148.7 & 0.02 & 16.8 & Yes \\
\hline Saglinsky RWS & Tyva & 96.8 & 0.04 & 61.0 & Yes \\
\hline Sut-Kholsky RWS & Tyva & 123.4 & No data & No data & No data \\
\hline Chagytaisky RWS & Tyva & 61.1 & 0.04 & 90.0 & No \\
\hline Shansky RWS & Tyva & 230.4 & 0.01 & 4.3 & No \\
\hline Eerbeksky RWS & Tyva & 241.8 & 0.06 & 35.6 & Yes \\
\hline Angirsky RWS & Buryatia & 423.3 & 0.05 & 16.1 & No \\
\hline Borgoysky RWS & Buryatia & 421.8 & 0.29 & 100 & Yes \\
\hline Tugnuisky RWS & Buryatia & 393.6 & 0.27 & 99.8 & Yes \\
\hline Aginskaya Steppe RWS & Trans-Baikal & 457.6 & 0.32 & 100 & Yes \\
\hline
\end{tabular}




\begin{tabular}{|l|l|c|c|c|c|}
\hline \multicolumn{1}{|c|}{ Protected Area } & Region & $\begin{array}{c}\text { Total area of } \\
\text { Protected Area* }\end{array}$ & $\begin{array}{c}\text { Percentage from total } \\
\text { area of all potential } \\
\text { habitats for the Pallas's } \\
\text { cat in Russia, \%* }\end{array}$ & $\begin{array}{c}\text { Percentage } \\
\text { from area of the } \\
\text { specific Protected } \\
\text { Area/site, \%* }\end{array}$ & $\begin{array}{c}\text { Has the Pallas's } \\
\text { cat existence been } \\
\text { confirmed in the last } \\
10-15 \text { years? }\end{array}$ \\
\hline Argaleisky RWS & Trans-Baikal & 120.0 & 0.01 & 12.1 & No \\
\hline Gornaya Steppe RWS & Trans-Baikal & 52.7 & 0.02 & 49.0 & Yes \\
\hline Semenovsky RWS & Trans-Baikal & 476.2 & 0.17 & 50.7 & Yes \\
\hline Oldondinsky RWS & Trans-Baikal & 515.0 & 0.34 & 94.5 & Yes \\
\hline $\begin{array}{l}\text { Total for regional Protected } \\
\text { Areas: }\end{array}$ & & 12309.1 & 4.06 & 47.9 & $34.7(37.3)$ \\
\hline $\begin{array}{l}\text { TOTAL (for all Protected } \\
\text { Areas): }\end{array}$ & & $\begin{array}{c}45095.9 \\
(52640.1)\end{array}$ & $10.8(13.5)$ & 2 \\
\hline
\end{tabular}

* Data in brackets are the percentage of potential habitats for the Pallas's cat as the Protected Areas are taken with their buffer zones (if any exist). Abbreviations used in the Table: BR - Biosphere Reserve, NP - National Park, FWS - federal Wildlife Sanctuary, NaP - Nature Park, RWS - regional Wildlife Sanctuary.

Four regional Protected Areas contain some areas of potential habitats for Pallas's cats. These are Ukok Quiet Zone Nature Park, Ak-Cholushpa Nature Park, Belukha Nature Park, and Shavlinsky Wildlife Sanctuary (Table 3). The last three are located in an area where the limit of the Pallas's cat's range passes. Anyway, the location of its range's limit requires clarification. The Pallas's cat's existence has been reliably confirmed in Shavlinsky Wildlife Sanctuary (Spitsyn, 2017), and it is assumed in Ak-Cholushpa Nature Park (Konunova et al., 2015; interview surveys).

In general, the regional Protected Areas cover about $17 \%$ of the total area of potential habitats of the Pallas's cat in the Republic of Altai. Both federal and regional Protected Areas cover almost $26 \%$ of the total area of potential habitats of the species in the region (Table 2).

\section{Republic of Tyva}

In Tyva the total area of potential habitats of the Pallas's cat is approximately $37,800 \mathrm{~km}^{2}$ (Table 2, Fig. 3). Perhaps, these habitats cover a greater area. There is a lack of data on the Pallas's cat's distribution in the western part of the Central Tyva hollow (Sut-Kholsky, Barun-Khemchiksky, and Bai-Taiginsky districts of the republic) and thus the potential habitats area has been apparently underestimated.

The Federal Protected Areas contain about 7\% of the total area of the Manul's potential habitats in the region. The Pallas's cat's habitats are located in one of the two federal Protected Areas in the Republic of Tyva - the Ubsunurskaya Kotlovina Biosphere Reserve. The Manul's habitats are located in seven of nine sites of this biosphere reserve and in their buffer zones, namely: Mongun-Taiga, Uvs Nuur, Oruku-Shynaa, Aryskannyg, Yamaalyg, Tsugeer Els and Khan-Deer sites (Table 2, 3).

There are also some Pallas's cat's habitats located in regional Protected Areas. These are Taiga
Nature Park, Balgazynsky Wildlife Sanctuary, Chagytaisky Wildlife Sanctuary, Kaksky Wildlife Sanctuary, Ondumsky Wildlife Sanctuary, Saglinsky Wildlife Sanctuary, Sut-Kholsky Wildlife Sanctuary, Eerbeksky Wildlife Sanctuary and, perhaps, Shansky Wildlife Sanctuary. The Balgazynsky and Chagytaisky ones are most appropriate for the Pallas's cat's inhabitation because $90-100 \%$ of their areas are suitable for them. To sum up, the regional Protected Areas cover about $2.9 \%$ from the total area of all potential habitats in the region, and ca. $10 \%$ of the total area of potential habitats in Tyva is located within regional and federal Protected Areas (Tables 2, 3).

In 2011, the Sibecocenter with assistance of the Ubsunurskaya Kotlovina Biosphere Reserve and the Directorate for the Protected Areas of the Republic of Tyva carried out special studies on distribution and abundance of the Pallas's cat in the republic including Protected Areas (Barashkova, 2012). In particular, our interview surveys were conducted in the buffer zones of four sites of the biosphere reserve (MongunTaiga, Aryskannyg, Yamaalyg, Tsugeer Els) and in the vicinity of them, in four regional wildlife sanctuaries (Kaksky, Ondumskiy, Saglinskiy, Eerbeksky), and in Taiga Nature Park. Snow track surveys were conducted in some of them, namely: Aryskannyg, Yamaalyg, and Tsugeer-Els sites of the BR, and Ondumsky Wildlife Sanctuary, as well as near the Balgazynsky Wildlife Sanctuary. The Pallas's cat's presence has been confirmed in all these Protected Areas.

In 2011, we estimated the total Manul's abundance in the Republic of Tyva at 4300-5800 individuals (Barashkova, 2012). At present, data on the Pallas's cat in the Ubsunurskaya Kotlovina Biosphere Reserve is obtained during monitoring of populations of other mammal species, including the use of camera traps (Kuksin et al., 2016; Goreva, 2017). In other Protected Areas of Tyva the Manul study is not carried out. 


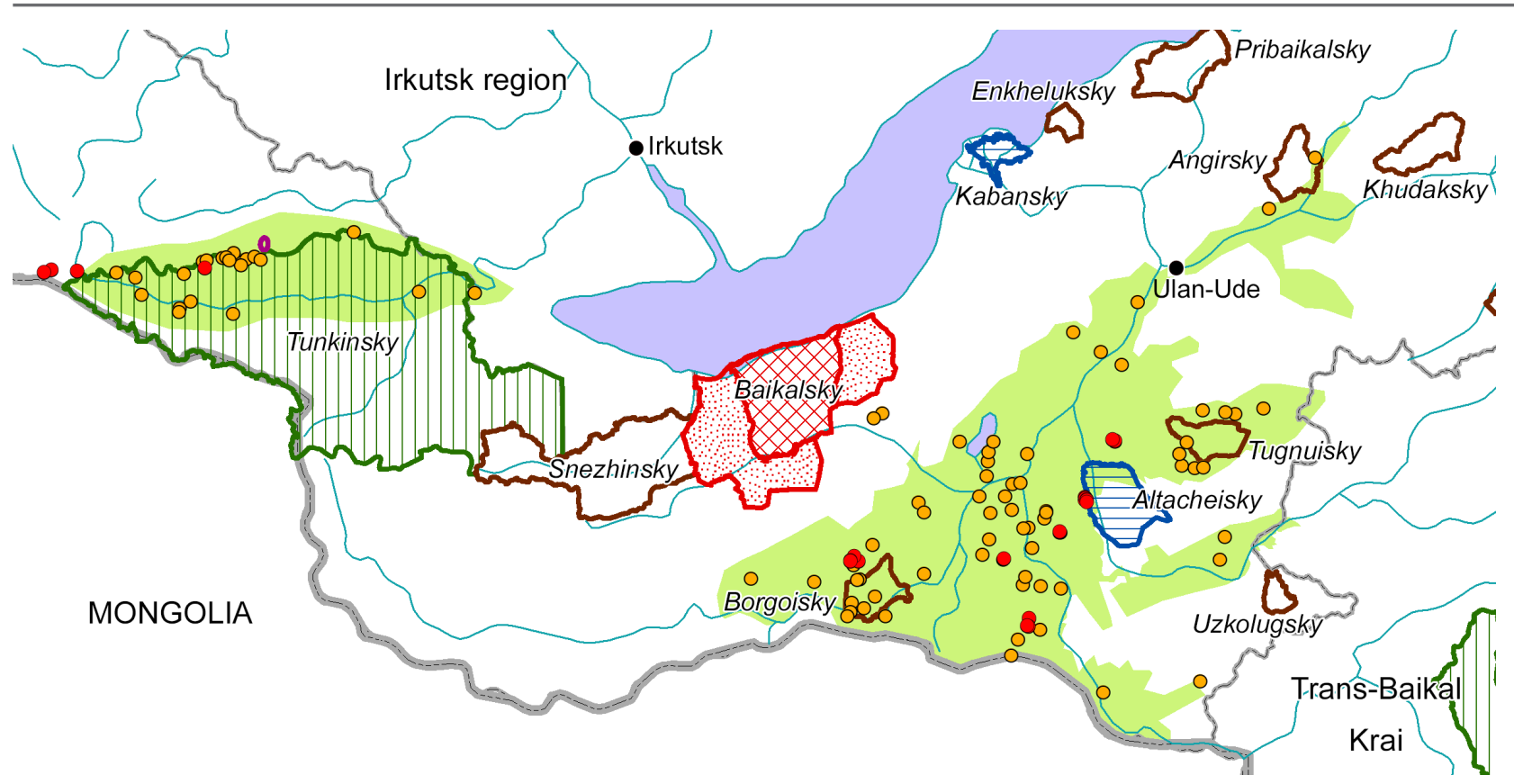

Fig. 4. Distribution of the Pallas's cat in the Baikal part of its Russian range. Legend see Fig. 3.

\section{Krasnoyarsk Krai}

The potential area of the Pallas's cat's inhabitation in the region is about $350 \mathrm{~km}^{2}$ near the boundary with Tyva (northern edge of the Central Tyva hollow) (Table 2, Fig. 3).

The Manul is recorded in both the core area and buffer zone of Sayano-Shushensky Biosphere Reserve (Sokolov, 2012; Istomov et al., 2016). The last authors (Istomov et al., 2016) made a summary of the Pallas's cat's records at the south of Krasnoyarsk Krai including the area of the biosphere reserve. They used Nature Chronicle materials, diary entries, inspectors' reports and data of the camera traps established in the Sayano-Shushensky BR to study the Snow Leopard. The total area of the Pallas's cat's inhabitation in the reserve has been estimated at $40 \mathrm{~km}^{2}$. According to our assessment, the total area potentially suitable for the Manul in the Sayano-Shushensky BR is about $200 \mathrm{~km}^{2}$. If our assessment is correct, this reserve provides the protection for about $57 \%$ of the total area of potential habitats of the Pallas's cat in the region.

\section{Republic of Buryatia}

In Buryatia the total area of potential habitats of the Pallas's cat has been estimated at not less than $28,900 \mathrm{~km}^{2}$. It consists of two isolated areas. The first of them is the Tunka fragment (about $6700 \mathrm{~km}^{2}$ ) located in the Eastern Sayan and Tunka valley. The second of them is the Southern-Buryatsky fragment (about 22,200 $\mathrm{km}^{2}$ ) which includes steppe valleys of the rivers Selenga, Chikoi, Khilok, and Dzhida (Table 2, Fig. 4).
More than $17 \%$ of the total area of potential habitats of the Pallas's cat in Buryatia is located within federal Protected Areas. These are mainly represented in the Tunkinsky National Park and in the Altacheisky Wildlife Sanctuary as well (Table 2,3). Approximately $3 \%$ of the total area suitable for the Pallas's cat is located within Borgoysky and Tugnuisky Wildlife Sanctuaries, and perhaps Angirsky as well.

Medvedev (2007) provided an overview of the Pallas's cat's records at the Tunka area in 1985-2006. The Manul's presence on the Tunka rocky summits has been confirmed during studies of the Snow Leopard using camera traps. In particular, the Pallas's cat has been repeatedly recorded in the vicinity of MunkuSardyk Mount located north of the Khövsgöl lake at the Russia/Mongolia border (Karnaukhov \& Malykh, 2017). This may indicate an existence of a direct connection between the Tunka enclave and the Mongolian population of the species via the Khövsgöl region and the Darkhat valley where the Pallas's cat was recorded (Litvinov \& Bazardorzh, 1992; Dorzhiev et al., 2009).

Studies of the Manul have not been carried out in the Tunkinsky National Park yet. Since 2015, Baikal Reserve carries out studies to identify the Pallas's cat habitats (using camera traps and snow track surveys) in the Altacheisky Wildlife Sanctuary and its vicinity (Shelest \& Khidekel, 2016; Shelest, 2017). In the winter of 2016-2017, the Buryat regional conservation body («BurPriroda») organised winter track surveys of the Pallas's cat in the regional wildlife sanctuaries. It is planned that this monitoring will become permanent in future (Doynikova, personal communication). 


\section{Trans-Baikal Krai}

In Trans-Baikal Krai the total area potentially inhabited by the Pallas's cat is ca. $62,100 \mathrm{~km}^{2}$ (the steppe region commonly known as Dauria). In 1994-1995, 2010, and 2016 the study of this region was conducted by us, including snow track and interview surveys as well as camera traps. About 7.9\% from the total area of potential habitats of the Pallas's cat in the region is located within federal Protected Areas and their buffer zones (Table 2). To a greater extent, these Protected Areas cover habitats which are optimal for the species. In certain years the Pallas's cat's population density at some areas here reaches 17.6-19.5 individuals per $10 \mathrm{~km}^{2}$ (Kirilyuk \& Barashkova, 2011). Currently, all cluster areas of the Daursky Reserve can be used by Pallas's cats and these are actually used by animals, including the bottom of the dried-up lake Barun-Torei. Optimal habitats are represented in Adon-Chelonsky and Kulusutaisky areas of the reserve. The Pallas's cat is known in all the territory of the Dzerens' Valley Wildlife Sanctuary established in 2011. The Manul visits regularly the Tsasucheisky Bor Wildlife Sanctuary. The Pallas's cat's existence has been confirmed in the buffer zone of the Sokhondinsky Biosphere Reserve (Belov, 2015) and, perhaps, in the Alkhanai National Park. Almost 2\% of the total area of potential habitats of the Manul in the TransBaikal Krai is located within five regional wildlife sanctuaries, namely: «Aginskaya Steppe», «Argaleisky», «Gornaya Steppe», «Semenovsky», and «Oldondinsky» (Table 3).

In the 1990s, studies of the Manul in the Daursky BR and Dauria as a whole were started. At that time, data of interview surveys and pedestrian investigations were generalised. By the mid-1990s, the species' number in the region was estimated at 2100-3000 individuals. The retrospective analysis of skins purchase data revealed multiple fluctuations in the Pallas's cat abundance with peak values up to 25,000 individuals in the 1940 s (Kirilyuk \& Puzansky, 2000). According to the recent surveys, the Pallas's cat's number in the region was estimated at 13,000-14,000 individuals in 2010 (Kirilyuk \& Barashkova, 2011) and 5,000-6,000 individuals in 2016 (Kirilyuk \& Barashkova, 2016). Multiple fluctuations of the Manul's number and distribution depending on the state of prey populations and snow cover have been shown exactly for Dauria. In unfavourable years Pallas's cats can move over dozens of kilometers which resulted in an increasing mortality. This behaviour decreases the role of Protected Areas in the species' conservation (Kirilyuk \& Barashkova, 2016). In addition, radiotelemetry studies have revealed vertical seasonal migrations of the Pallas's cats in the rugged terrain. In snowy winters, Pallas's cats move into the relief depressions, where the average snow depth is less.

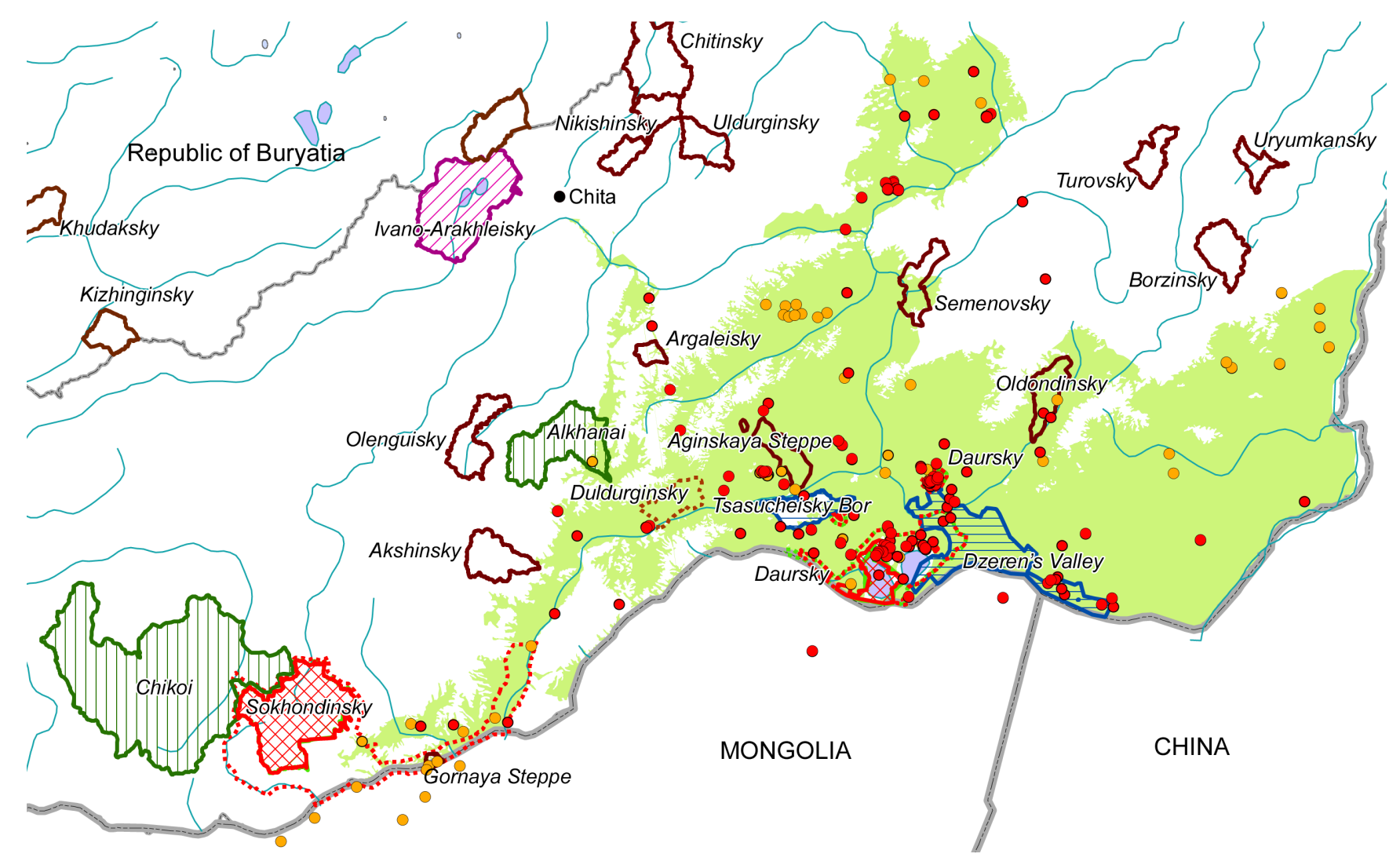

Fig. 5. Distribution of the Pallas's cat in the Trans-Baikal part of its Russian range. Legend see Fig. 3. 
The analysis of radiotelemetry studies conducted in the Daursky Biosphere Reserve has allowed making preliminary conclusions on the structure and dynamics of individual home ranges of Pallas's cats (Barashkova \& Kirilyuk, 2011). However, the ground-based radiolocation using the VHF transmitters has not allowed establishing the patterns of Pallas's cat's migrations into new habitat areas. Analogous studies conducted in similar landscapes in Mongolia have shown that the individual home ranges of Pallas's cats are on average significantly larger than those of many other medium size predators (Ross et al., 2012). And therefore, only large Protected Areas can secure protection of viable Pallas's cat populations.

\section{General characteristics of Pallas's cat protection by Protected Areas}

In total, eleven federal Protected Areas are located within the area of the Pallas's cat distribution in Russia. These are five biosphere reserves (Altaisky, Daursky, Sayano-Shushensky, Sokhondinsky, Ubsunurskaya Kotlovina), three national parks (Sailugemsky, Tunkinsky, Alkhanai), and three federal wildlife sanctuaries (Altacheisky, Dzerens' Valley, Tsasucheisky Bor) (Table 3). Totally, these Protected Areas include about 6.7\% from the total area of the potential habitats of the Manul in Russia, or $9.5 \%$ if also taking into account the buffer zones of the Protected Areas (Table 2).

In the Russian legislation a buffer zone is not a part of a Protected Area but has a special regime that can be similar to one of the wildlife sanctuaries. It is sufficient to protect the Pallas's cat and its habitats against main threats.

Regional Protected Areas (nature parks and wildlife sanctuaries) cover $4.1 \%$ of the total area of potential habitats of the Pallas's cat.

In total, Protected Areas of different categories and levels cover $10.8 \%$ of the total area of Manul habitats in Russia, or $13.5 \%$ if taking buffer zones into account.

In general, it may seem that the existing Russian Protected Areas are sufficient to provide a good protection of the Pallas's cat. However, the protection level varies significantly in different parts of the national species range. The Pallas's cat's habitats are least covered by the Protected Areas in the west of the range in Russia, in its Altai-Sayan part. It is especially correct for Tyva (Table 2, Fig. 3) where all Protected Areas contain less than $5 \%$ of the total area of the habitats suitable for this species (less than $10 \%$ if the buffer zones are included). Then, the Manul range in
Tyva consists of two or three fragments corresponding to the large intermontane depressions dominated by steppe landscapes. The fragments are more or less isolated. Most of the Protected Areas which include the Pallas's cat's habitats are located in the Uvs Nuur basin but only few of them are in the Central Tyva hollow (despite its large area) and only single records of the species are known in these Protected Areas (less than $5 \%$ of the total number of the Manul records in the province). The habitats of the Pallas's cat in Altai are formally better protected. But only $5 \%$ or less of the actually known Manul registration points are located within Protected Areas.

Taking into account the distribution of the Pallas's cat's records it can be seen that there are significant gaps in its coverage by the Protected Areas in both Baikal and Trans-Baikal parts of the species range. Thus most of the Pallas's cat registrations in Buryatia are confined to the interfluves of the river Selenga with the river Chikoi and the river Chikoi with the river Khilok, and to the basin of lake Gusinoe. But there is not any Protected Area in these locations. The habitats of the Pallas's cat in the Trans-Baikal Krai are not covered by the Protected Areas in the Argun ridge and north of Urulyunguy ravine, nor north of Shilka (systems of the river Nercha and the river Quenga) where this species is located on the northern border of its range in the region. Despite of extremeness, the last mentioned location is the only area where Pallas's cats have not been affected by catastrophic decline during the severe winter of 2015-2016 (Kirilyuk \& Barashkova, 2016). This fact highlights the potential importance of this location for conservation of the Pallas's cat in the region.

Existing Protected Areas are not sufficient to counteract the high mortality rate of the Pallas's cat in the «bad» years either (when it is affected by extreme weather and/or low feeding supply). The Protected Areas should contain also lowlands and river valleys in the steppe zone, while known surviving areas should be protected as well.

\section{References}

Barashkova A. 2005. What is known about Pallas's cat in Russia. Steppe Bulletin 19: 29-32. [In Russian]

Barashkova A. 2012. New data on Pallas's cat in Tyva. Steppe Bulletin 35: 44-48. [In Russian]

Barashkova A.N., Kirilyuk V.E. 2011. On study of Pallas's cat home ranges by radiotelemetry method. In: Remote methods of research in zoology. Moscow: KMK Scientific Press Ltd. P. 8. [In Russian]

Barashkova A., Smelansky I. 2011. Pallas's cat in the Altai Republic, Russia. Cat News 54: 4-7. 
Barashkova A.N., Smelansky I.E. 2016. Photo records of mammals in South-Eastern Altai (Kosh-Agach district, Altai Republic). In: Biodiversity, ecological issues of Gorny Altai and its neighbouring regions: present, past, and future. Gorno-Altaisk: Gorno-Altaisk State University Press. P. 26-29. [In Russian]

Barashkova A.N., Smelansky I.E., Tomilenko A.A., Naidenko S.V., Dambain A.B. 2010. Towards the abundance and distribution of Pallas's cat (Otocolobus manul) in the Republic of Altai. In: Mountain ecosystems of South Siberia: study, conservation and rational use. Proceedings of the Tigirek State Natural Reserve 3: 287-289. [In Russian]

Barashkova A., Chestina A., Goreva N., Denisov A., Karnaukhov A., Karyakin I., Kirilyuk V., Kuzhlekov A., Malikov D., Naidenko S., Rovero F., Shelest E., Shtol D., Smelansky I., Spitsyn S., Tsyrendashiev T., Vinner N. 2017. Pallas's cat (Otocolobus manul). In: Small wild cats of Eurasia (Web-GIS «Faunistics»). Electronic online-database. Available at: http://wildcats.wildlifemonitoring.ru. Downloaded on 30.03.2017.

Belov I. 2015. Pallas's cat in left banks of upper Onon river. Steppe Bulletin 45: 68-69. [In Russian]

Denisov A.V., Eshelkin I.I., Filatov E.I., Polkovnikov E.S., Sheffer V.V., Sanarov P.P., Abibulaev D.E. 2015. Meetings with Pallas's cat in Kosh-Agach district of the Republic of Altai. In: Endangered, rare and less studied animal species and its presence in the Red Data Book of Altai Republic of previous and future editions. GornoAltaisk. P. 115-118. [In Russian]

Dorzhiev Ts.Z., Dashanimaev V.M., Zhavzmaa N., Tamir Zh. 2009. About some species of the steppe mammals of Darkhat hollow (Mongolia). Buryat State University Bulletin 4: 154-158. [In Russian]

Gadghiev I.M., Korolyuk A.Yu., Titlyanova A.A., Andievsky V.S., Bayartogtokh B., Grishina L.G., Kosykh N.P., Kyrgys Ch.O., Mironycheva-Tokareva N.P., Romanova I.P., Sambuu A.D., Smelansky I.E. 2002. Steppes of Inner Asia. Novosibirsk: SB RAS Publisher. 299 p. [In Russian]

Goreva N. 2017. Pallas's cat (Otocolobus manul). In: Small wild cats of Eurasia (Web-GIS «Faunistics»). Electronic online-database. Available at: http://wildcats.wildlifemonitoring.ru. Downloaded on 05 April 2017.

Hammer Ø., Harper D.A.T., Ryan P.D. 2001. PAST: Paleontological Statistics Software Package for Education and Data Analysis. Palaeontologia Electronica 4(1): 9.

Istomov S.V., Khritankov A.M., Shishikin A.S., Kozhechkin V.V. 2016. Pallas's cat in the south of Krasnoyarsk Krai. Mordovia Reserve 11: 35-38. [In Russian]

Kalikhman T.P., Bogdanov V.N., Ogorodnikova L.Yu. 2012. Protected areas of the Siberian Federal District. Atlas. Irkutsk: Publisher «Ottisk». 384 p. [In Russian]

Karnaukhov A., Malykh S. 2017. Pallas's cat (Otocolobus manul). In: Small wild cats of Eurasia (Web-GIS «Faunistics»). Electronic online-database. Available at: http://wildcats.wildlifemonitoring.ru. Downloaded on 30 March 2017.

Kirilyuk V.E. 1999. On Pallas's cat (Felis manul Pall., 1778) nutrition and behaviour in the southeastern Trans-Baikal region. Bulletin of Moscow Society of Naturalists 104(6): 41-44. [In Russian]
Kirilyuk V.E., Barashkova A.N. 2011. Assessment of abundance and main factors influencing the population status of Pallas's cat in Trans-Baikal Krai. The report on institutional contract. 17 p. [In Russian]

Kirilyuk V.E., Barashkova A.N. 2016. Control estimation of Pallas's cat abundance in the pilot Protected Area in Dauria. The final report. 8 p. [In Russian]

Kirilyuk V.E., Puzansky V.A. 2000. Distribution and abundance of Pallas's cat in the South-East of Trans-Baikal Krai. Bulletin of Moscow Society of Naturalists 105(3): 3-9. [In Russian]

Konunova A.N., Konunov Yu.A., Olchonov A. 2015. Short data on rare mammals of the Eastern Altai. In: Endangered, rare and less studied species of animals and its presence in Red Data Book of Altai Republic of previous and future editions. Gorno-Altaisk. P. 168-169. [In Russian]

Kuksin A.N., Goreva N.A., Barashkova A.N. 2016. Modern status of Pallas's cat (Otocolobus manul Pallas, 1776) in Tyva. In: Modern status of rare plants and animals in the Republic of Tyva.. Kyzyl. P. 76-81. [In Russian]

Litvinov N.I, Bazardorzh D. 1992. Mammals of TransHubsugul region (The Mongolian National Republic). Irkutsk: Publisher of the Irkutsk State University. 136 p. [In Russian]

Map of Protected Areas of Russian Federation. In: Informational-Analytic System «Protected Areas of Russia». AARI, laboratory of geoinformatic technologies, 2017. Available at: http://oopt.aari.ru/oopt_map. Downloaded on 12 April, 2017

Map of remained steppe ecosystems (steppe massifs) of Russia. In: Steppe Conservation in Russia - web-site on conservation, restoration and non-destructive use of steppe ecosystems and associated species of plants and animals. 2017. Available at: http://savesteppe.org/ maps. Retrieved on 12 April, 2017.

Medvedev D.G. 2007. Manul in the Eastern Sayan and Tunka valley. Bulletin of the East Siberian Scientific Center of the Siberian Branch of the Russian Academy of Medical Sciences 2(Suppl.): 93-96. [In Russian]

Naidenko S.V., Smelansky I.E., Barashkova A.N. 2007. Pallas's cat (Otocolobus manul) status in the southeast of Altai Republic. In: Theriofauna of Russia and contiguous territories. Moscow: KMK Scientific Press Ltd. P. 322. [In Russian]

Naidenko S.V., Pavlova E.V., Kirilyuk V.E. 2014. Detection of seasonal weight loss and a serologic survey of potential pathogens in wild Pallas' cats (Felis [Otocolobus] manul) of the Daurian steppe, Russia. Journal of Wildlife Diseases 50(2): 188194. DOI: 10.7589/2013-03-068

Pavlova E.V., Kirilyuk V.E., Naidenko S.V. 2015. Patterns of seroprevalence of feline viruses among domestic cats and Pallas' cats in Daurskii Reserve, Russia. Canadian Journal of Zoology 93: 849-855. DOI: 10.1139/cjz-2015-0006

Red Data Book of Russian Federation (Animals). Moscow: Astrel, 2001. 860 p. [In Russian]

Red Data Book of the Krasnoyarsk Krai. The Rare and Endangered Species of Animals; $3^{\text {rd }}$ edition, revised and added. Krasnoyarsk: Siberian Federal University, 2012. 205 p. [In Russian] 
Red Data Book of the Republic of Altai. Animals. GornoAltaisk, 2007. 400 p. [In Russian]

Red Data Book of the Republic of Buryatia. Rare and endangered species of animals, plants and fungi. UlanUde: Publisher of Buryat Scientific Centre of Siberian Branch of RAS, 2013. 688 p. [In Russian]

Red Data Book of the Republic of Tyva: animals. Novosibirsk, 2002. 168 p. [In Russian]

Red Data Book of the Trans-Baikal Krai. Animals. Novosibirsk: Novosibirsk Publishing House, 2012. 344 p. [In Russian]

Red Data Book of the USSR: Rare and endangered species of animals and plants. Moscow: Lesnaya promyshlennost, 1978. 460 p. [In Russian]

Red Data Book of the USSR: Rare and endangered species of animals and plants. Vol. 1. $2^{\text {nd }}$ edition. Moscow: Lesnaya promyshlennost, 1984. 392 p. [In Russian]

Report on scientific work «Monitoring of animal species, listed in the Red Data Book of Russian Federation, in the Republic of Tyva. Section: data on population status of Pallas's cat in Tyva». Kyzyl, 2006 (manuscript). [In Russian]

Ross S., Munkhtsog B., Harris S. 2012. Determinants of mesocarnivore range use: relative effects of prey and habitat properties on Pallas's cat home-range size. Journal of Mammalogy 93(5): 1292-1300. DOI: 10.1644/11-MAMM-A-060.1

Ross S., Barashkova A., Farhadinia M.S., Appel A., Riordan P., Sanderson J., Munkhtsog B. 2016. Otocolobus manul. The IUCN Red List of Threatened Species 2016: e.T15640A87840229. Available at: http://dx.doi.org/10.2305/IUCN.UK.2016-1.RLTS. T15640A87840229.en. Downloaded on 30 March 2017.
Shelest E. 2017. Pallas's cat (Otocolobus manul). In: Small wild cats of Eurasia (Web-GIS «Faunistics»). Electronic online-database. Available at: http://wildcats.wildlifemonitoring.ru. Downloaded on 05 April, 2017.

Shelest E.N., Khidekel V.V. 2016. Manul in Buryatia: existing data and perspectives of study. In: Biodiversity: global and regional processes. Ulan-Ude: Publisher of Buryat Scientific Centre of Siberian Branch of RAS. P. 130-131. [In Russian]

Sokolov G.A. 2012. Manul. In: A.P. Savchenko (ed.): Red Data Book of Krasnoyarsk Krai. Vol. 1. Rare and endangered species of animals. Krasnoyarsk: Siberian Federal University. P. 147. [In Russian]

Spitsyn S. 2017. Pallas's cat (Otocolobus manul). In: Small wild cats of Eurasia (Web-GIS «Faunistics»). Electronic online-database. Available at: http:// wildcats.wildlifemonitoring.ru. Downloaded on 30 March, 2017.

The report on ecological situation in Trans-Baikal Krai in 2015. Chita, 2016a. 215 p. [In Russian]

The report on the status and protection of environment in the Republic of Altai in 2015. Gorno-Altaisk, 2016b. 120 p. [In Russian]

The state report on the status and protection of environment in Krasnoyarsk Krai in 2015. Krasnoyarsk, 2016a. 314 p. [In Russian]

The state report on the status and protection of environment in the Republic of Buryatia in 2015. Ulan-Ude, 2016b. 249 p. [In Russian]

The state report on the status and protection of environment in the Republic of Tyva in 2015. Kyzyl, 2016c. 140 p. [In Russian]

\title{
ЗНАЧЕНИЕ ОСОБО ОХРАНЯЕМЫХ ПРИРОДНЫХ ТЕРРИТОРИЙ ДЛЯ СОХРАНЕНИЯ МАНУЛА (ОTOCOLOBUS MANUL: FELIDAE) В РОССИИ
}

\author{
А. Н. Барашкова ${ }^{1}$, В. Е. Кирилюк ${ }^{2}$, И. Э. Смелянский ${ }^{1}$ \\ ${ }^{1}$ Сибэкоичентр, Россия \\ ${ }^{2}$ Государственный природный биосферный заповедник "Даурский», Россия \\ e-mail:yazula@yandex.ru
}

\begin{abstract}
Otocolobus manul является видом мелких кошачьих и находится в России на северной периферии своего ареала. На основе данных дистанционного зондирования Земли, топокарт и цифровых картографических моделей в пределах российского ареала манула выделены потенциальные местообитания этого вида. По литературным источникам, собственным данным авторов и данным, предоставленным вкладчиками он-лайн базы данных, составлена карта находок (регистраций) манула в России. Рассмотрена представленность потенциальных местообитаний манула и его фактических регистраций в сети ООПТ на территории России. Всего в пределах ареала вида в России площадь потенциальных местообитаний составляет 145150 км². Во всех пяти регионах, где подтверждено обитание манула (республики Алтай, Тыва и Бурятия, Красноярский и Забайкальский края), регистрация его встреч в основном соответствует размещению потенциальных местообитаний. Основными категориями федеральных и региональных ООПТ охвачено $10.8 \%$ (с учетом охранных зон - 13.5\%) от площади потенциальных местообитаний манула; детально рассмотрен потенциал каждой из этих ООПТ для сохранения манула. Обсуждается, достаточна ли существующая сеть ООПТ для сохранения вида. Указаны основные территориальные пробелы, снижающие защищенность манула территориальной охраной в отдельных частях российского ареала.
\end{abstract}

Ключевые слова: Otocolobus manul, защищенность территориальной охраной, манул, он-лайн база данных, особо охраняемые природные территории, потенциальные местообитания, пробелы территориальной охраны, распространение 